\title{
IMPLEMENTASI METODE ELECTRE UNTUK MENENTUKAN KELAYAKAN PEMBERIAN KREDIT SEPEDA MOTOR PADA PERUSAHAAN LEASING
}

\author{
Dinil Lativa ${ }^{1}$,Poningsih ${ }^{2}$, Jalaluddin $^{3}$
}

${ }^{1}$ Mahasiswa Program Studi Sistem Informasi STIKOM Tunas Bangsa Pematang Siantar

${ }^{2,3}$ AMIK Tunas Bangsa Pematangsiantar, Indonesia

Email: 1dinillativa21@gmail.com, ${ }^{2}$ Poningsih@amiktunasbangsa.ac.id, ${ }^{3}$ jallaluddin@amiktunasbangsa.ac.id

\begin{abstract}
Abstrak
Perusahaan leasing merupakan pembiayaan peralatan atau barang modal yang digunakan untuk proses produksi suatu perusahaan, baik secara langsung maupun tidak langsung. Pembiayaan melalui leasing merupakan pembiayaan yang sangat sederhana dalam prosedur dan pelaksanaannya dan oleh karena itu leasing yang digunakan sebagai pembayaran alternatif tampak lebih menarik. Sebagai suatu alternatif sumber pembiayaan modal bagi perusahaan khususnya di bagian credit analyst. Dalam kegiatan pengambilan keputusan konsumen layak kredit, diperlukan model sistem berbasis komputer yang dapat memberikan kemudahan dalam melakukan analisa data, perhitungan penilaian kriteria pemohon kredit, serta membantu pengolahan data menjadi informasi untuk mengambil keputusan dari masalah semi terstruktur tersebut. Sebuah sistem keputusan (SPK) merupakan pilihan tepat untuk membantu penyeleksian pemohon kredit. Sistem dirancang dengan metode Elimination and Choice Translating Reality (ELECTRE) yang merupakan salah satu metode perhitungan multi kriteria berdasarkan peta konsep outrangking dengan menggunakan perbandingan berpasangan dari alternatif lain berdasarkan setiap kriteria.
\end{abstract}

Kata kunci: ELECTRE, Credit Analyst ,Kredit, Leasing

\begin{abstract}
Leasing companies are financing equipment or capital goods that are used for the production process of a company, both directly and indirectly. Financing through leasing is a very simple financing in the procedures and implementation and therefore leasing that is used as an alternative payment seems more attractive. As an alternative source of capital financing for companies, especially in the credit analyst section. In credit-worthy consumer decision-making activities, a computer-based system model that can provide data analysis, calculation of criteria for credit applicants, and help processing data into information to make decisions from the semi-structured problem is needed. A decision system (DSS) is the right choice to help select credit applicants. The system is designed with the Elimination and Choice Translating Reality (ELECTRE) method which is one of the multi criteria calculation methods based on the outrangking concept map by using paired comparisons of other alternatives based on each criterion. The data used in this paper are in the form of alternative data samples, criteria data, criteria weight, and suitability rating for each alternative to the criteria.
\end{abstract}

Keywords: ELECTRE, Credit Analyst ,Kredit, Leasing

\section{PENDAHULUAN}

PT Federal International Finance merupakan perusahaan leasing yang memberikan jasa kredit dan mengambil keuntungan dari pembayaran bunga kredit. Pembiayaan konsumen adalah pembiayaan yang dilakukan secara angsuran sampai tanggal yang ditentukan. Penelitian ini menggunakan metode ELECTRE yaitu salah satu metode pengambilan keputusan multikriteria berdasarkan pada konsep outranking dengan menggunakan perbandingan berpasangan dari alternatif-alternatif berdasarkan setiap kriteria yang sesuai[1].

Satu kendala yang menyebabkan pendapatan perusahaan berkurang adalah kredit macet. Kredit macet adalah keadaan dimana konsumen kredit sudah tidak sanggup membayar sebagian atau seluruh kewajibannya kepada perusahaan seperti yang telah diperjanjikan, sehingga perlu dilakukan seleksi yang didasarkan pada analisis data pemohon kredit. dalam kegiatan pengambilan keputusan konsumen layak kredit, diperlukan sebuah model sistem pendukung keputusan berbasis komputer yang dapat memberikan kemudahan dalam melakukan analisa data. Sistem Pendukung Keputusan (SPK) atau Decision Support System (DSS) adalah sebuah sistem yang mampu memberikan kemampuan pemecahan masalah maupun kemampuan pengkomunikasian untuk masalah dengan kondisi semi terstruktur dan tak terstruktur. Sistem ini digunakan untuk membantu pengambilan keputusan dalam situasi semi terstruktur dan situasi yang tidak terstruktur, dimana tak seorangpun tahu secara pasti bagaimana keputusan seharusnya dibuat[2]. ELECTRE merupakan salah satu metode pengambilan keputusan multikriteria berdasarkan pada konsep outrangking dengan menggunakan perbandingan berpasangan dari alternatif-alternatif berdasarkan setiap kriteria yang sesuai[3]. Maka dari itu dalam upaya membantu perusahaan dalam kegiatan pengambilan keputusan konsumen layak kredit, diperlukan sebuah model sistem keputusan berbasis komputer yang dapat memberikan kemudahan dalam melakukan analisa data, perhitungan dan penilaian kriteria pemohon kredit.

Dengan adanya penelitian ini diharapkan dapat membantu mempercepat proses analisa data dan penilaian terhadap konsumen sesuai dengan faktor-faktor yang dijadikan acuan dalam pengambilan keputusan oleh perusahaan PT. Federal International Finance Cabang Pematang siantar. Mempercepat pengambilan keputusan untuk calon pemohon kredit sepeda motor sehingga prosesnya lebih cepat dan akurat. Sebagai referensi bagi peneliti selanjutnya yang berkaitan dengan data Pemberian kelayakan kredit sepeda motor.

\section{TEORITIS}




\subsection{Sistem Pendukung Keputusan}

Sistem Pendukung Keputusan atau sering disebut Decision Support System (DSS) adalah sistem berbasis model yang terdiri dari prosedur-prosedur dalam pemrosesan data dan pertimbangannya untuk membantu manager dalam mengambil keputusan[4] Sistem Pendukung Keputusan ini berbasis komputer dan digunakan sebagai tambahan dari kemampuan untuk penyelesaian suatu masalah dari seseorang.

Adapun langkah langkah dalam pembangunan SPK menurut adalah sebagai berikut :

1. Studi Kelayakan (Intelligence) pada langkah ini, sasaran ditentukan dan dilakukan pencarian prosedur, pengumpulan data, identifikasi masalah, identifikasi kepemilikan masalah, klasifikasi masalah, hingga akhirnya terbentuk sebuah pernyataan masalah.

2. Perancangan (Design) pada tahap ini akan diformulasikan model yang akan digunakan dan kriteri-kriteria yang ditentukan. Setelah itu dicari alternatif model yang bisa menyelesaikan permasalahan tersebut. Langkah selanjutnya adalah memprediksi keluaran yang mungkin kemudian ditentukan variable-variabel model.

3. Pemilihan (Choice) Setelah pada tahap perencanaan ditentukan berbagai alternatif model beserta variabel-variabel nya. Pada tahapan ini akan dilakukan pemilihan modelnya,termasuk solusi dari model tersebut. Selanjutnya, dilakukan analisis sensivitas, yakni dengan mengganti beberapa variabel.

4. Membuat SPK setelah menentukan modelnya, berikutnya adalah mengimplementasikannya dalam aplikasi SPK.

\subsection{Algoritma Elimination and Choice Translation Realiy (ELECTRE)}

Metode ELECTRE merupakan salah satu metode pengambilan keputusan multikriteria berdasarkan pada konsep outranking dengan menggunakan perbandingan berpasangan dari alternatif-alternatif berdasarkan setiap kriteria yang sesuai[1][5] .

Metode ELECTRE digunakan untuk kasus-kasus dengan banyak alternatif namun hanya sedikit kriteria yang dilibatkan. Suatu alternatif dikatakan mendominasi alternatif yang lainnya jika suatu atau lebih kriteria melebihi (bandingkan dengan kriteria dari alternatif yang lain) dan sama dengan kriteria lain yang tersisa.

Tahap-tahap metode ELECTRE dapat dilihat seperti dibawah ini : [6][7]

Tahap 1 : Menentukan Matriks Keputusan

Pada kolom-kolom yang tersedia, terdapat matriks kriteria keputusan (n) dan baris pada form alternatif (m).

sebagai tahap awal dan dasar pemrosesan pada pendukung keputusan.

$$
r_{i j}=\left[\begin{array}{ccccc}
x_{11} & x_{12} & x_{13} & \ldots & x_{1 n} \\
x_{21} & x_{22} & x_{23} & \ldots & x_{2 n} \\
\cdot & \cdot & \cdot & \ldots & \cdot \\
x_{m 1} & x_{m 2} & x_{m 3} & \ldots & x_{m n}
\end{array}\right]
$$

Tahap 2 : Normalisasi Matriks Keputusan

Matriks keputusan akan dinormalisasi dengan menggunakan rumus dan menghasilkan model ternormalisasi.

$$
\begin{aligned}
& r_{i j}=\frac{x_{i j}}{\sqrt{\sum_{i=1}^{m} X_{i j}^{2}}} \\
& \mathrm{i}=1,2, \ldots, \mathrm{m} \\
& \mathrm{j}=1,2, \ldots, \mathrm{n}
\end{aligned}
$$

Hasil proses matriks keputusan ternormalisasi, seperti dibawah ini :

$$
r_{i j}=\left[\begin{array}{ccccc}
r_{11} & r_{12} & r_{13} & \ldots & r_{1 n} \\
r_{21} & r_{22} & r_{23} & \ldots & r_{2 n} \\
\cdot & \cdot & \cdot & . . & \cdot \\
r_{m 1} & r_{m 2} & r_{m 3} & \ldots & r_{m n}
\end{array}\right]
$$

Tahap 3 : Pemberian Nilai Bobot

Keterangan selanjunya, pembuat keputusan menyediakan factor minat (bobot) pada setiap kriteria yang menyatakan nilai kepentingan relative $(\mathrm{Wj})$

$\sum_{j=1}^{n} W j=1$

$\mathrm{W}=(\mathrm{W} 1, \mathrm{~W} 2, \ldots, \mathrm{Wn})$

Tahap 4 : Menghitung Matriks Ternormalisasi Terbobot

Setiap kolom pada matriks $\mathrm{R}$ dikalikan dengan bobot $(\mathrm{Wj})$ yang ditentukan oleh pembuat keputusan dapat dilihat dibawah ini.

$v_{I J}=$ Wi Rij

Dimana $\mathrm{V}$ adalah

$v_{I J}=\left[\begin{array}{ccccc}v_{11} & v_{12} & v_{13} & \ldots & v_{1 n} \\ v_{21} & v_{22} & v_{23} & \ldots & v_{2 n} \\ \cdot & \cdot & \cdot & \ldots & \cdot \\ v_{m 1} & v_{m 2} & v_{m 3} & \ldots & v_{m n}\end{array}\right]$

Tahap 5 : Menetukan Himpunan Concordance dan Discordance 
Himpunan concordance $\{\mathrm{CK} 1\}$ menyatakan bahwa hitungan kriteria bobot AK dengan kemungkinan lain lebih baik daripada A1.

$C_{k l}=\{\mathrm{j} \mid \mathrm{Vkj} \geq \mathrm{V} \mathrm{ij}\}$ dengan $\mathrm{j}=1,2, \ldots$,

Himpunan discordance $\left\{\mathrm{DK}_{1}\right\}$ tertulis sebagai berikut :

$D_{k l=}\{\mathrm{j} \mid \mathrm{Vkj} \leq \mathrm{V} \mathrm{ij}\}$ dengan $\mathrm{j}=1,2, \ldots, \mathrm{n}$

Tahap 6 : Menghitung Matriks Concordance dan Discordance

Untuk menghitung atau menetukan matriks concordance adalah dengan cara menambah bobot yang terdapat dalam matriks concordance.

$$
C_{k l}=\sum_{j \in C k l} W j
$$

Untuk menetukan matriks discordance adalah dengan membagi selisih maksimum kriteria yang dimasukkan kedalam himpunan discordance dengan selisih tertinggi diantara nilai-nilai yang ada pada semua kriteria.

$D_{k l}=\frac{\max \{|\mathrm{Vkj}-\mathrm{Vij}|\} j \in C k l}{\max \{|\mathrm{Vkj}-\mathrm{Vij}|\} v j}$

Matriks D juga hasil m x m dan tidak mengambil nilai kolom 1 dan baris k, array d sebagai berikut.

$d_{i j}=\left[\begin{array}{cccc}- & d_{12} & \ldots & d_{1 n} \\ d_{21} & - & \ldots & d_{2 n} \\ \cdot & \cdot & - & \cdot \\ d_{m 1} & d_{m 2} & \ldots & -\end{array}\right]$

Tahap 7 : Menentukan matriks Concordance dominan dan Discordance dominan. Array ini dapat membentuk nilai ambang atas (threshold) $\underline{\mathrm{C}}$. Rumus yang dapat menghasilkan nilai c.

$$
\underline{c}=\frac{\sum_{k=1}^{m} \sum_{k=1}^{m} C_{k l}}{m(m-1)}
$$

Alternatif AK dapat memiliki kesempatan untuk mendominasi Aı jika indeks konkrodansi CKı melebihi nilai ambang atas $\underline{\mathrm{C}}$ dengan $\mathrm{CK \imath} \geq \underline{\mathrm{C}}$ dan_elemen matriks concordande dominan $\mathrm{F}$ didefenisikan sebagai :

$f_{k l}=\frac{1, \text { jika } \mathrm{CK \iota}_{2} \geq \mathrm{C}}{0, \text { jika } \mathrm{CK \iota}_{\mathrm{C}}<\mathrm{C}}$

Hal yang sama juga dilakukan kepada matriks dominan matriks diskordansi G dengan nilai ambang atas $\underline{D}$. rumus berikut dapat memberikan nilai $\mathrm{D}$.

$\underline{d}=\frac{\sum_{k=1}^{m} \sum_{k=1}^{m} D_{k l}}{m(m-1)}$

Elemen matriks discordance dominan $\mathrm{G}$ ditetapkan sebagai :

$g_{k l=\frac{1, \text { jika Dкl } \geq \mathrm{D}}{0, \text { jika DкL }<\mathrm{D}}}$

Tahap 8 : Menentukan Matriks Dominan Keseluruhan

Model E sebagai total matriks dominan adalah matriks dimana setiap elemen dikalikan diantara elemen matriks $\mathrm{F}$ dan bentuk persamaan elemen $\mathrm{G}$.

$e_{k l}=f_{k l} * g_{k l}$

\section{ANALISA DAN PEMBAHASAN}

\subsection{Analisis Data}

Metode analisis data terdiri atas dua macam, yaitu metode static deskriptif dan metode statistik inferensial. Data yang digunakan berupa data kriteria dengan pembobotan sesuai dengan rating kepentingannya. Data kriteria yang digunakan dalam penentuan calon nasabah yang berhak menerima kredit sepeda motor dapat dilihat dari tabel 1 . berikut.

Tabel 1. Pemberian Bobot Kriteria

\begin{tabular}{cllcc}
\hline No & \multicolumn{1}{c}{ Kriteria } & Bobot \\
\hline 1 & $\mathrm{C}_{1}$ & Gaji & $25 \%$ & 4 \\
2 & $\mathrm{C}_{2}$ & Uang Muka & $15 \%$ & 3 \\
3 & $\mathrm{C}_{3}$ & Pekerjaan & $30 \%$ & 5 \\
4 & $\mathrm{C}_{4}$ & Tanggungan & $15 \%$ & 3 \\
5 & $\mathrm{C}_{5}$ & Kepemilikan Rumah & $15 \%$ & 3 \\
\hline
\end{tabular}

\subsection{Algoritma Sistem}

Sebelum memasuki tahap perhitungan dengan algoritma ELECTRE, penulis akan membuat ratng kecocokan terlebih dahulu yang penulis dapatkan dari hasil observasi dan wawancara yang penulis sebelumnya. Berikut tabel rating kecocokan calon nasabah kredit sepeda motor yaitu :

Tabel 2. Rating Kecocokan

\begin{tabular}{lllllll}
\hline \multirow{2}{*}{ No Alternatif } & \multicolumn{6}{c}{ Kriteria } \\
& C1 & C2 & C3 & $C^{2}$ & C5 \\
\hline
\end{tabular}




\begin{tabular}{ccccccc}
\hline 1 & $\mathbf{A 1}$ & 3 & 3 & 3 & 3 & 4 \\
2 & $\mathbf{A 2}$ & 3 & 2 & 2 & 3 & 1 \\
3 & $\mathbf{A 3}$ & 3 & 3 & 2 & 3 & 4 \\
4 & $\mathbf{A 4}$ & 3 & 2 & 2 & 3 & 4 \\
5 & $\mathbf{A 5}$ & 4 & 3 & 2 & 3 & 4 \\
6 & $\mathbf{A 6}$ & 2 & 2 & 3 & 3 & 4 \\
7 & $\mathbf{A 7}$ & 3 & 2 & 3 & 3 & 4 \\
8 & $\mathbf{A 8}$ & 4 & 2 & 4 & 3 & 4 \\
9 & $\mathbf{A 9}$ & 3 & 3 & 2 & 3 & 4 \\
10 & $\mathbf{A 1 0}$ & 2 & 2 & 3 & 3 & 4 \\
\hline
\end{tabular}

Setelah keseluruhan data yang diperlukan seperti kriteria, bobot kriteria, sampel alternatif, serta rating kecocokan alternatif terhadap kriteria yang telah tersedia, maka langkah selanjutnya adalah melakukan perhitungan dengan menggunakan algoritma ELECTRE sebagai berikut :

1. Menentukan Matriks Keputusan

Matriks keputusan ditentukan dari Tabel 3. sebelumnya yang kemudian disusun kedalam matriks keputusan menggunakan persamaan (1). Sehingga didapatlah matriks keputusan sebagai berikut.

$$
x i j=\left[\begin{array}{lllll}
3 & 3 & 3 & 3 & 4 \\
3 & 2 & 2 & 3 & 1 \\
3 & 3 & 2 & 3 & 4 \\
3 & 2 & 2 & 3 & 4 \\
4 & 3 & 2 & 3 & 4 \\
2 & 2 & 3 & 3 & 4 \\
3 & 2 & 3 & 3 & 4 \\
4 & 2 & 4 & 3 & 4 \\
3 & 3 & 2 & 3 & 4 \\
2 & 2 & 3 & 3 & 4
\end{array}\right]
$$

2. Normalisasi Matriks Keputusan

Membuat normalisasi matriks keputusan dapat dilakukan dengan menggunakan persamaan (2).

3. Pemberian Nilai Bobot

Berdasarkan Tabel 3.1. maka didapatlah nilai bobot kriteria sebagai berikut :

$W=(25 \%, 15 \%, 30 \%, 15 \%, 15 \%)$

Sehingga jika dihitung menggunakan persamaan (5), didapatlah

$\sum_{j=1}^{n} W_{j}=25 \%+15 \%+30 \%+15 \%+15 \%=100 \%=1$

4. Menghitung Nilai Bobot

5. Matriks Ternormalisasi Terbobot

Penulis tidak menggunakan persamaan(3), dikarenakan kriteria yang penulis gunakan merupakan parameter keuntungan, dan bukanlah parameter harga.

6. Pemberian Nilai Bobot

Berdasarkan Tabel 3.1. maka didapatlah nilai bobot kriteria sebagai berikut :

$W=(25 \%, 15 \%, 30 \%, 15 \%, 15 \%)$;

Sehingga jika dihitung menggunakan persamaan (5), didapatlah

$\sum_{j=1}^{n} W_{j}=25 \%+15 \%+30 \%+15 \%+15 \%=100 \%=1$

7. Menghitung Nilai Bobot

8. Matriks Ternormalisasi Terbobot

9. Pada proses ini, penulis menggunakan nilai bobot yang lebih sederhana untu memudahkan perhitungan yang sebeumnya telah tertera pada tabel 1 .

10. Menghitung matriks ternormalisasi terbobot dilakukan dengan menggunakan persaman (6)

11. Menentukan Himpunan Concordance dan Discordance Himpunan concordance dihitung dengan menggunakan persamaan (8),

12. Menghitung Matriks Concordance dan Matriks Discordance Matriks concordance dihitung menggunakan persamaan (10)

13. Menentukan Matriks Corcodance Dominan dan Matriks Discordance Dominan

Sebelum membuat matriks corcodance dominan, terlebih dahulu harus menentukan nilai ambang $\mathrm{C}$ dengan menggunakan persamaan (13), 
14. Mengeliminasi alternatif yang Kurang Baik

Berdasarkan matriks dominan keseluruhan sebelumnya, didapatlah hasil sebagai berikut.

\begin{tabular}{ccc}
\multicolumn{3}{c}{ Tabel 5. Hasil Penilaian Alternatif } \\
\hline Alternatif & Nilai & Peringkat \\
\hline A6 & 2 & I \\
A7 & 1 & II \\
A1 & 1 & III \\
A2 & 0 & IV \\
A3 & 0 & V \\
A4 & 0 & VI \\
A5 & 0 & VII \\
A8 & 0 & VIII \\
A9 & 0 & IX \\
A10 & 0 & X \\
\hline
\end{tabular}

Berdasarkan tabel 5 diatas dapat dilihat bahwa calon nasabah penerima kredit diprioritaskan kepada Alternatif A6 dengan nilai $=2$, A7 dengan nilai $=1$, A1 dengan nilai $=1$, sedangkan calon nasabah yg tereliminasi adalah alternatif A2,A3,A4,A5,A8,A9,A10 dengan nilai $=0$.

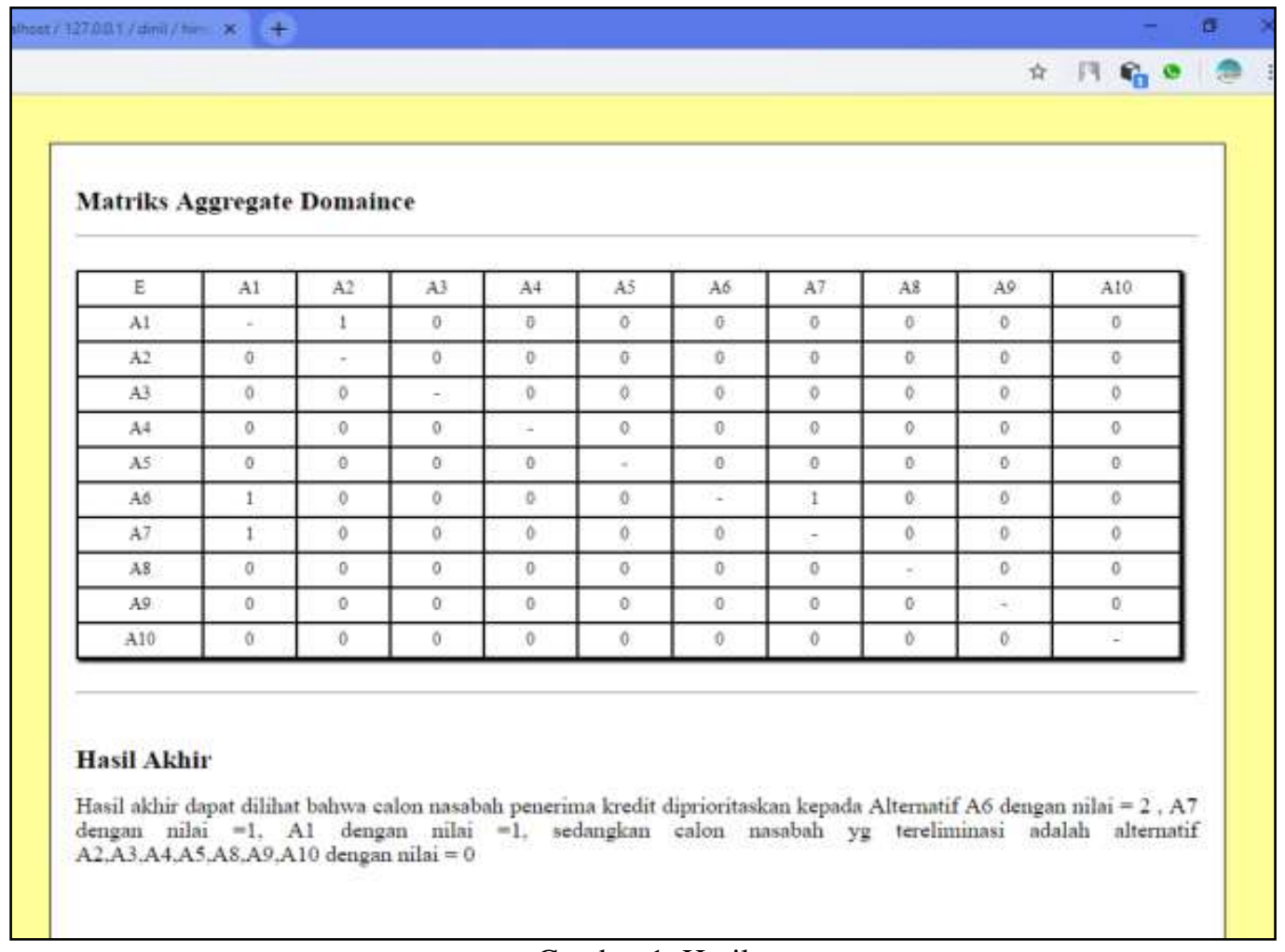

Gambar 1. Hasil

Matrik E memberikan urutan pilihan dari setiap alternatif, yaitu bila $e_{k l}=1$ maka alternatif $A_{k}$ merupakan alternatif yang baik dari $A_{1}$, sehingga baris dari matrik $\mathrm{E}$ yang memiliki $e_{k l}=1$ paling sedikit dapat di eliminasi dan yang memiliki $e_{k l}$ terbanyak merupakan alternatif terbaik. Sehingga disimpulkan bahwa alternative nasabah yang layak kredit terbaik adalah Alternatif A6 dengan total nilai = 3 dan dapat dilihat pada gambar 1.

\section{KESIMPULAN}

1. Dengan adanya sistem pendukung keputusan dengan metode ELECTRE untuk menentukan kelayakan pemberian kredit sepeda motor pada Perusahaan Leasing, dapat membantu dalam memberikan rekomendasi dan pertimbangan dalam memilih calon nasabah kredit sepeda motor sesuai kriteria yang telah ditetapkan oleh perusahaan.

2. Dan berdasarkan hasil akhir yang diperoleh baik menggunakan perhitungan secara manual maupun secara komputerisasi menunjukkan bahwa hasil yang sama, yaitu alternatif A6 yang terpilih sebagai alternatif terbaik dalam menentukan kelayakan pemberian kredit sepeda motor. 


\section{REFERENCES}

[1] F. Setiawan, F. Indriani, And Muliadi, Implementasi Metode Electre Pada Sistem Pendukung Keputusan Snmptn Jalur Undangan, Kumpul. J. Ilmu Komput., Vol. 2, No. 2, Pp. 88-101, 2015.

[2] Saefudin And Irwan, Sistem Pendukung Keputusan Menentukan Lokasi Event Pt . Mitra Panglima Sejahtera ( Mps ) Honda Pandeglang Menggunakan Metode Electre, J. Sist. Inf., Vol. 5, No. 1, Pp. 18-25, 2018.

[3] L. Marlinda, Sistem Pendukung Keputusan Pemilihan Tempat Wisata Yogyakarta Menggunakan Metode Elimination Et Choix, Semin. Nas. Sains Dan Teknol., Pp. 1-7, 2016.

[4] A. W. Oktaputra, Sistem Pendukung Keputusan Kelayakan Pemberian Kredit Motor Menggunakan Metode Simple Additive Weighting Pada Perusahaan Leasing Hd Finance, J. Spk Kelayakan Pemberian Kredit Mot., Pp. 1-9, 2014.

[5] S. Sundari, A. Wanto, And I. Gunawan, Sistem Pendukung Keputusan Dengan Menggunakan Metode Electre Dalam Merekomendasikan Dosen Berprestasi Bidang Ilmu Komputer ( Study Kasus Di Amik \& Stikom Tunas Bangsa ), In Prosiding Seminar Nasional Multi-Disiplin Ilmu (Senasmudi), 2017, Pp. 1-6.

[6] H. J. Damanik, I. Parlina, H. S. Tambunan, And E. Irawan, Sistem Pendukung Keputusan Dalam Seleksi Penyiar Radio Boss Fm 102.8 Pematang Siantar Menggunakan Metode Electre, Komik (Konferensi Nas. Teknol. Inf. Dan Komputer), Vol. I, Pp. 38-44, 2017.

[7] S. R. Ningsih, I. S. Damanik, I. Gunawan, And W. Saputra, Electre Dalam Menentukan Penerima Program Indonesia Pintar (Pip) Melalui Kartu Indonesia Pintar (Kip) (Studi Kasus: Sd Swasta Al - Washliyah Moho Kabupaten Simalungun), Komik(Konferensi Nas. Teknol. Inf. Dan Komputer), Vol. I, No. 1, Pp. 264-275, 2017. 